\title{
Post Thoracotomy Pain Syndrome
}

\author{
F. Della Corte, C. Mendola, A. Messina and G. Cammarota \\ Azienda Ospedaliera Maggiore della Carità, Novara,
}

Italia

\section{Introduction}

Post-thoracotomy pain is one of the most severe and long lasting complications after surgery (1-4) which acutely contributes to limit normal respiratory activity impairing the sputum clearance and reducing ventilatory function (5). Along with limb amputation, thoracotomy is the surgical procedure with the highest risk of severe and long lasting acute postoperative pain (6).

Moreover, a chronic post thoracotomy pain syndrome (PTPS) may delay the long term rehabilitation, worsening the quality of life because of the associated neuropathic pain even without recurrences of the primary disease (7). Lung cancer still remains the first cause of death for cancer (8) and prompt pulmonary surgery may be the only effective therapeutic strategy. Consequently, an increasing rate of thoracic surgery will be progressively associated with a higher PTPS incidence in the future.

The syndrome was firstly described in 1944 during the II world war when American surgeons reported persistent intercostal pain in soldiers submitted to thoracotomy (9). Until the end of the nineties, pain treatment was mainly based on intravenous opioids and the incidence of PTPS was about $61 \%$ one year after surgery (10).

\section{Definition and incidence}

The International Association for the Study of Pain (IASP) definition of Post Thoracotomy Pain Syndrome is the following: 'Pain that recurs or persists along a thoracotomy scar at least 2 months following surgical procedure' (7).

PTPS incidence between 11 and $80 \%$ has been reported in the literature (11-13). This variability is probably related to the setting of retrospective studies, the lack of an homogeneous definition of the severity and duration of the syndrome, the difference in anesthetic and analgesic protocols, the use of different pain evaluation scales and the time of postoperative follow-up. Moreover, the high variability in PTPS incidence may also be explained by the different attitude of patients towards discomfort (14).

\section{Pain characteristics after thoracic surgery}

PTPS is mostly described with the typical characteristics of neuropathic pain, often related to the surgical scar, since $82-90 \%$ of pain patients recognize the pain trigger directly to the surgical site $(1,10)$. Pain is primarily described as aching, tender, with numbness and to a lesser degree burning $(1,15)$; however, PTPS is sometimes described as tingling and pruritus sensation within the thoracic injured area. Finally, thoracic sensory deficits are referred by 
patients in terms of sensory loss and hypoesthesia to cold $(16,17)$. These neuropathic phenomena are principally located within mammary and sub mammary areas and ipsilateral scapular and interscapular regions.

Comparing to acute postoperative pain, PTPS does not specifically influence the respiratory function but may be able to limit daily activities. In other words, differences between acute and chronic pain are more related to the inability to restore the physiological functions of the organism to homeostatic pre-thoracotomy levels (18). Even if the pain intensity is moderate, normal daily activities might be hampered up to $50 \%$ of cases and sleep disorders could be present in the $25 \%$ of patients (10); finally, severe pain could be present in $8 \%$ and can persist in more than $40 \%$ of cases (15). Unfortunately the social consequences and subsequent analgesic use have only been recorded in a minority of studies with different design $(4,13,15,19,20)$ so that the actual impact of chronic pain on daily life remains undefined.

\section{Pathogenetic features}

The mechanisms that lead to PTPS are multiple and the pathogenesis is still unclear. The pathway of the painful experience related to thoracotomy is complex. Inputs from skin, muscles, ribs, and parietal pleura are conducted through intercostal nerves to the dorsal horn. Moreover, the vagus nerve and the autonomic system are involved in the conduction of noxious stimuli from visceral pleura and lung parenchyma; finally, the phrenic nerve is related to noxious stimuli from mediastinum, diaphragm and pericardial pleura $(21,22)$.

Although the pathogenesis of chronic neuropathic post thoracotomy pain syndrome is complex, the direct damage of intercostal nerves and the consequent effect on pain transmission seems to play a primary role (23). Many important peripheral and central nociceptive adaptions have been described after peripheral nerve injury (23).

Peripherally, ephaptic conduction or "cross-excitation" generated by neurons linked to injured nerves may trigger a distorted pathway of nociceptive stimuli which may be clinically relevant for the ongoing neuropathic pain $(23,24)$. Moreover, in these neurons the expression of sodium and calcium channels may be altered $(23,25,26)$. A collateral sprouting of fibers from sensory axons into denervated areas has been also described in an animal model, but the degree of sprouting was not proportional to the degree of hyperalgesia after nerve section so that the role of this phenomenon seems to be limited (23, 27). Another important role may be played by direct coupling of the sympathic nerve system and the sensory nervous system in the dorsal root gangliation (28). The trigger signal of this sprouting is still unclear but the release of neurotrophic factors and cytokines following wallerian degeneration is likely to be decisive (29).

Central mechanisms are also implicated in the development of this syndrome (23). The nerve injury is coupled to a considerable degree of spinal cord reorganization. Largediameter, low threshold A-beta fibres from mechanoceptors may wrongly sprout into lamina II, which is normally the termination of high-threshold A-delta and C fibres, leading to an erroneous interpretation of nociceptive stimuli (30). Peripheral nerve injury, similarly to chronic inflammation, is coupled to a persistent state of hyperexcitability of the dorsal horn neurons, a process called "central sensitization" $(31,32)$. The excitatory amino acid glutamate is known to be the major excitatory neurotransmitter related to noxious stimulation. Many postsynaptic receptors are linked to glutamate release but a strong evidence suggests that N-methyl-D-aspartate (NMDA) receptor subtype is the main 
involved in both inflammation and central sensitization (33). The gamma - amminobutirric acid (GABA) pathway represents the major inhibition system in the CNS. The suppression of this pathway with pharmacological inhibitors is associated with a dose-dependent allodynia (34). GABA receptors level is reduced after peripheral nerve axotomy, maybe because of primary degeneration of afferent neuron terminals on which the receptor is localized. The consequent reduction in GABA activity may play an important role in central sensitization (35). A separate pathway of nociceptive modulation in CNS is the purinergic system, including specifically adenosine. Neuropathic patients show a reduction in adenosine concentration in both circulating blood and CSF, suggesting a concurrent effect of adenosine in the modulation of chronic pain (36).

Finally, the reduced ability of opiates in relieving neuropathic pain is widely accepted but the exact extent of this phenomenon is controversial. The dose response function of opiates seems to be unfavorably shifted to the right (23). This clinical evidence may be explained by loss of peripheral opiate effect, loss of spinal opiate receptors and increased activity in physiological opioid antagonism system (23).

\section{Factors influencing the prevalence of PTPS}

\subsection{Predisposing factors for the development of chronic pain are:}

- $\quad$ Female gender $(13,37)$.

- $\quad$ Age under 60 years $(37,38)$

- Genetic factors: genetic control of pain involves several genes such as catecholOmethyltransferase (COMT), voltage-gated sodium channels, and GTP cyclohydrolase and tetrahydrobiopterin-related genes which are characterized by high level of variability in the population $(39,40)$.

- Psychological factors: anxiety, depression, malignant disease and social status, may play a determinant role in influencing perception and consequences of chronic pain (13, $41,42)$. However the relationship between preoperative psychological factors and PTPS should be investigated with targeted study.

- Preoperative pain and analgesic consumption: the relationship between preoperative pain and analgesic consumption and the development of chronic pain is well established for some kinds of surgery $(43,44)$. Moreover, assessing the preoperative pain threshold of each patient may be useful to identify risking patients at risk of postoperative pain which may lead to chronification (electrical, heat, cold and pressure tests) (45-49). Unfortunately, the role of pre-surgical pain in PTPS recurrence is still controversial $(13,45,50,51)$.

\subsection{Perioperative factors are the:}

- Type and extent of surgery (intercostal nerve damage, resection of the chest wall, pleurectomy and pneumectomy)

- Intensity and duration of pain during the first postoperative day.

\subsubsection{The type and extent of surgery}

Many surgical approaches for thoracic cavity are described: median sternotomy, bilateral transverse thoracosternotomy, posterolateral thoractomy, muscle sparing thoracotomy and video-assisted thoracoscopy (VATS) (52). 
Intercostal nerves are primarily involved in the rib cage pain transmission. The incision of the skin, soft tissue and muscles triggers an inflammatory response. The retraction of the intercostal space, and sometimes the resection of the ribs themselves, increases the damage to the costovertebral and costotrasversal ligaments with the subsequent involvement of the parietal pleura (53).

The intercostal nerve can be compressed by retractors or damaged during rib resection and closure of chest wall or can be trapped by sutures and healing processes. Nociception from mediastinic and diaphragmatic pleura is transmitted by different nervous pathways (phrenic and vagus nerves). This type of pain is deep and poorly localized. Moreover, this painful sensation triggered by diaphragmatic injury is also referred to the homolateral shoulder pain. Pleural drainage also produces deep pain due to both skin incision and pleural irritation.

In addition to surgical injury, the breathing cycle constantly involves the damaged structures, enhancing the trigger of thoracic pain.

The diagnosis of nerve injury is often associated with allodynia and/ or hyperalgesia plus numbness distributed in the area served by affected nerves.

The type of incision is strictly associated to post-thoracotomy pain and damage of intercostal nerves (54). The posterolateral thoracotomy, sparing serratus anterior and trapezius muscles, seems to minimize damaging in intercostal nerves compared to the standard posterolateral thoracotomy. Consequently, this technique is associated with a reduction of pain and improvement mobility of the ipsilateral shoulder in the first seven postoperative days.

However, several studies have questioned these results in terms of both acute and chronic pain after one year. An anterior axillary approach has been proposed to reduce the painful symptoms, but the benefit was not still confirmed by the literature. The technique used for closure of the chest wall may play a role in the intercostal nerve damage.

Nevertheless, all the different surgical approaches described above, may lead either to acute and chronic pain. This finding may be firstly explained by frequent anatomical variants in the intercostal nerves course so that their integrity is not ensured by any surgical choice. Moreover, the surgical retractor, used in all the techniques, may probably play an important role in the damage of the intercostal nerves.

The video-assisted thoracic surgery (VATS) seems to reduce the incidence of PTPS, probably because of multiple small incisions that produce a smaller nerve injury than open thoracotomy. However VATS does not preserve intercostal nerve from damage because the scope may crush nervous fibers against adjacent rib. Moreover the use of retractors to take away the lung section may also damage intercostals nerve (63-27). In conclusion VATS technique does not prevent the PTPS development but seems to reduce the PTPS incidence compared to muscle sparing incision (28)

\subsubsection{The intensity and duration of pain during the first postoperative day}

Several prospective studies show that the most important predictor for the development of PTPS is the persistent post surgical pain which is strictly related to the severity of acute postoperative pain. Acute postoperative pain, in fact, is related to the amount of intercostal nerves damaged $(55,56)$. However, some studies found no clear relationship between PTPS and intensity of acute postoperative pain $(1,4,10)$. The literature is not exhaustive because no study evaluates overall preoperative, intraoperative and postoperative factors which can influence the incidence of PTPS. Undoubtely, the strict pain control is mandatory in this kind of surgery. 


\subsection{Postoperative factors}

\subsubsection{Social consequences}

The social impact of PTPS as capability to influence daily activites and consequently quality of life were investigated by several studies $(4,10,13,15,20)$. Commonly the effects of PTPS are registered in the following activities: standing, sitting, getting up, sleep. Even if the pain intensity is moderate, normal daily activities could be hampered up to $50 \%$ of cases and sleep disorders could be present in the $25 \%$ of patients (10); finally severe pain could be present in $8 \%$ and it's not relieved in more than $40 \%$ of cases (50). However, because of lack of right evaluation of this kind of disabilities, the exact impact of PTPS on social field must be better investigated.

\subsubsection{Disease relapse - chemo and radio therapy}

Keller et all (57) suggest that relapse of disease can uncontrovertibly rise PTPS incidence. However, even if this data is obvious and well comprehensible, much more data are needed to support this evidence. Moreover, since no data are available about the effects of chemo and radio-therapy on PTPS incidence, several studies must be encouraged to understand their role on PTPS incidence.

\section{Prevention and treatment strategies of PTPS}

\subsection{Intra and postoperative analgesia}

Postoperative analgesia is commonly based on the use of regional anesthesia and systemic drug infusion. Different regional anesthesia techniques have been used: mostly thoracic epidural anesthesia (TEA) $(58,59)$, thoracic paravertebral block (PVB) $(60)$, and, secondarily, pleural infusion or intercostal nerves block. The role of intrapleural infusion, intercostal nerve block and local infiltration in reducing PTPS is still unclear because studies evaluating this analgesic technique are confounding and lacking of exhaustive data (45).

TEA and PVB with opioids and local anesthetics mixture are the most used regional techniques. Nowadays, TEA is still considered the gold standard technique even if PVB has recently emerged as valid alternative to TEA (61).

However the role of TEA in reducing PTPS remains controversial and questionable. In any case, multimodal analgesia using different modalities as regional and systemic analgesic techniques is highly recommended (61).

On the contrary, there is no consensus on the drug to use for adjunct intravenous analgesia. Ketamine has been confirmed as a useful agent $(62,63)$ while COX-2 inhibitors, celecoxib i.e, were recently proposed as a valid alternative (64). Besides, only few studies reported about the efficacy of the $S(+)$ - isomer of Ketamine (65) that has been demonstrated to have twice the anaesthetic and analgesic potency of the racemic ketamine preparation and is judged to induce less psychic emergence reactions, a reduced number of hallucinations (66) and to be followed by a more rapid recovery of vigilance $(67,68)$ preserving the hypoxic pulmonary vasoconstriction, enhancing oxygenation and decreasing shunt fractions in monopulmonary ventilation (52).

Only few trials have demonstrated the effect of iv ketamine as an adjunct to TEA. Suzuki et al (69) demonstrated the efficacy of $0,05 \mathrm{mg} \mathrm{Kg}^{-1} \mathrm{~h}^{-1}$ racemic ketamine combined with TEA with ropivacaine and morphine on acute pain control until 3 months postoperatively but not at 6 months follow-up. Dualé et al (63) confirmed that racemic ketamine ( $1 \mathrm{mg} \mathrm{kg}^{-1} \mathrm{~h}^{-1}$ during surgery and $1 \mathrm{mg} \mathrm{kg}^{-1} \mathrm{~h}^{-1}$ in the first 24 hours) was effective in the immediate postoperative 
pain but failed to prevent a reduction of chronic PTPS at 6 weeks and 4 months after surgery.

S-(+)-isomer of Ketamine has been demonstrated to be more effective than the racemic mixture with a lower incidence of side effects. Argiriadou et al (65) recently proposed the use of the $\mathrm{S}(+)$-isomer of Ketamine in conjunction with thoracic paravertebral ropivacaine providing better early postoperative pain relief than ropivacaine alone or in adjunction with perecoxib.

In the last years a great interest has been elicited by the use of the preemptive analgesia and the administration of Ketamine during and after surgery to prevent and lessen the processes involved in the development of neuropathic pain (70) even if some contrasting results have been published on the use of Ketamine for postoperative pain control (71).

Patients treated with TEA in pre-empty modality with opioids and local anesthetics showed a lower incidence of chronic PTPS if compared to patients who received only intravenous opioids (72). Moreover, the exclusive intravenous administration of opioids may induce hyperalgesia and tolerance to opioids themselves, both processes NMDA receptors activation mediated (73).

NMDA receptors antagonists may prevent the acute tolerance to opioids and, among them, ketamine at a blood concentration of $30-120 \mathrm{ng} \mathrm{ml}^{-1}$ is able to strengthen the nociceptives effects of opioids without altering sedation indexes (74).

The preoperative administration of $0.1 \mathrm{mg} / \mathrm{Kg}$ epidural ketamine reduced the area affected by hyperalgesia and allodynia around the surgical wound in the first 30 days after incision; the same dosage given intramuscolarly did not produce the same effects (75). The limitations to these observations are that the neuropathic lesion and pain could appear after a period longer than expected (76).

The administration of NMDA receptors inhibition is hampered by the need of a prolonged administration which could be more efficient via an oral route administration (77).

\section{Conclusions}

Many progresses have been done in the identification and the pathophysiological understanding of PTPS even if we are far from a well defined understanding of this syndrome. From the clinical point of view the priority resides on the continuous collaboration among anesthetists, surgeons, pharmacists and nurses to guarantee to any patient the best approach and the most correct pharmacological therapy.

Multimodal analgesia using different modalities as regional and systemic analgesic techniques is highly recommended (61).

In our opinion, pain unit in the management of patients undergoing thoracotomy is likely to warrant intensive and aggressive pain control with multimodal strategy in order to assure high level of comfort in the perioperative period and consequently reduce the incidence of PTPS.

\section{References}

[1] Kalso E, Perttunen K, Kaasinen S. Pain after thoracic surgery. Acta Anaesthesiol Scand 1992; 36: 96-100.

[2] Kavanagh BP, Katz J, Sandler AN. Pain control after thoracic surgery. A review of current techniques. Anesthesiology 1994; 81: 737-59. 
[3] Richardson J, Smith T, Tsiamis A, Shah RD. Postthoracotomy pain. Ann Thorac Surg 1998; 65: 300-2.

[4] Tiippana E, Nilsson E, Kalso E. Post-thoracotomy pain after thoracic epidural analgesia: a prospective follow-up study. Acta Anaesthesiol Scand 2003; 47: 433-8.

[5] Fiore JF, Jr., Chiavegato LD, Denehy L, Paisani DM, Faresin SM. Do directed cough maneuvers improve cough effectiveness in the early period after open heart surgery? Effect of thoracic support and maximal inspiration on cough peak expiratory flow, cough expiratory volume, and thoracic pain. Respir Care 2008; 53: 1027-34.

[6] Nikolajsen L, Ilkjaer S, Kroner K, Christensen JH, Jensen TS. The influence of preamputation pain on postamputation stump and phantom pain. Pain 1997; 72: 393-405.

[7] Merskey H. Classification of chronic pain syndromes and definition of pain terms. Pain 1986; suppl: S138-S9.

[8] Shaw A, Keefe FJ. Genetic and environmental determinants of postthoracotomy pain syndrome. Curr Opin Anaesthesiol 2008; 21: 8-11.

[9] Blades B, Dugan DJ. War wounds of the chest observed at the Thoracic Surgery Center, Walter Reed General Hospital. J Thorac Surg 1944; 13: 294-306.

[10] Perttunen K, Tasmuth T, Kalso E. Chronic pain after thoracic surgery: a follow-up study. Acta Anaesthesiol Scand 1999; 43: 563-7.

[11] Rogers ML, Duffy JP. Surgical aspects of chronic post-thoracotomy pain. Eur J Cardiothorac Surg 2000; 18: 711-6.

[12] Gottschalk A, Cohen SP, Yang S, Ochroch EA. Preventing and treating pain after thoracic surgery. Anesthesiology 2006; 104: 594-600.

[13] Ochroch EA, Gottschalk A, Augostides J, et al. Long-term pain and activity during recovery from major thoracotomy using thoracic epidural analgesia. Anesthesiology 2002; 97: 1234-44.

[14] Landreneau RJ, Mack MJ, Hazelrigg SR, et al. Prevalence of chronic pain after pulmonary resection by thoracotomy or video-assisted thoracic surgery. J Thorac Cardiovasc Surg 1994; 107: 1079-85; discussion 85-6.

[15] Maguire MF, Ravenscroft A, Beggs D, Duffy JP. A questionnaire study investigating the prevalence of the neuropathic component of chronic pain after thoracic surgery. Eur J Cardiothorac Surg 2006; 29: 800-5.

[16] Gotoda Y, Kambara N, Sakai T, Kishi Y, Kodama K, Koyama T. The morbidity, time course and predictive factors for persistent post-thoracotomy pain. Eur J Pain 2001; 5: 8996.

[17] Guastella V, Mick G, Soriano C, et al. A prospective study of neuropathic pain induced by thoracotomy: incidence, clinical description, and diagnosis. Pain; 152: 74-81.

[18] Erdek MA, Staats PS. Chronic pain and thoracic surgery. Thorac Surg Clin 2005; 15: 12330.

[19] Hu JS, Lui PW, Wang H, et al. Thoracic epidural analgesia with morphine does not prevent postthoracotomy pain syndrome: a survey of 159 patients. Acta Anaesthesiol Sin 2000; 38: 195-200.

[20] Dajczman E, Gordon A., Kreisman H. Wolkove N. Long-therm postthoracotomy pain. Chest 1991; 99: 270-4.

[21] Klafta JM. Impact of acute pain and its management for thoracic surgical patients. In: Ferguson MK (Ed.). Thoracic surgery clincs; 2005: 849-65. 
[22] Hazelrigg SR, Cetindag IB, Fullerton J. Acute and chronic pain syndromes after thoracic surgery. Surg Clin North Am 2002; 82: 849-65.

[23] Bridges D, Thompson SW, Rice AS. Mechanisms of neuropathic pain. Br J Anaesth 2001; 87: 12-26.

[24] Gracely $R H$, Lynch SA, Bennett GJ. Painful neuropathy: altered central processing maintained dynamically by peripheral input. Pain 1992; 51: 175-94.

[25] Dib-Hajj SD, Fjell J, Cummins TR, et al. Plasticity of sodium channel expression in DRG neurons in the chronic constriction injury model of neuropathic pain. Pain 1999; 83: 591-600.

[26] Waxman SG, Kocsis JD, Black JA. Type III sodium channel mRNA is expressed in embryonic but not adult spinal sensory neurons, and is reexpressed following axotomy. J Neurophysiol 1994; 72: 466-70.

[27] Devor M, Schonfeld D, Seltzer Z, Wall PD. Two modes of cutaneous reinnervation following peripheral nerve injury. J Comp Neurol 1979; 185: 211-20.

[28] Janig $W$, Levine JD, Michaelis $M$. Interactions of sympathetic and primary afferent neurons following nerve injury and tissue trauma. Prog Brain Res 1996; 113: 161-84.

[29] Ramer MS, Thompson SW, McMahon SB. Causes and consequences of sympathetic basket formation in dorsal root ganglia. Pain 1999; Suppl 6: S111-20.

[30] Woolf CJ, Shortland P, Coggeshall RE. Peripheral nerve injury triggers central sprouting of myelinated afferents. Nature 1992; 355: 75-8.

[31] Wall PD. Neuropathic pain and injured nerve: central mechanisms. Br Med Bull 1991; 47: 631-43.

[32] Coderre TJ, Katz J, Vaccarino AL, Melzack R. Contribution of central neuroplasticity to pathological pain: review of clinical and experimental evidence. Pain 1993; 52: 25985.

[33] Doubell TP MR, Woolf CJ. The dorsal horn: State-dependent sensory processing, plasticity and the generation of pain. In: Livingstone C (Ed.). Textbook of pain. London; 1999: 165-82.

[34] Yaksh TL. Behavioral and autonomic correlates of the tactile evoked allodynia produced by spinal glycine inhibition: effects of modulatory receptor systems and excitatory amino acid antagonists. Pain 1989; 37: 111-23.

[35] Sivilotti L, Woolf CJ. The contribution of GABAA and glycine receptors to central sensitization: disinhibition and touch-evoked allodynia in the spinal cord. J Neurophysiol 1994; 72: 169-79.

[36] Guieu R, Peragut JC, Roussel P, et al. Adenosine and neuropathic pain. Pain 1996; 68: 2714.

[37] Kehlet H, Jensen TS, Woolf CJ. Persistent postsurgical pain: risk factors and prevention. Lancet 2006; 367: 1618-25.

[38] Pluijms WA, Steegers MA, Verhagen AF, Scheffer GJ, Wilder-Smith OH. Chronic postthoracotomy pain: a retrospective study. Acta Anaesthesiol Scand 2006; 50: 804-8.

[39] Diatchenko L, Nackley AG, Tchivileva IE, Shabalina SA, Maixner W. Genetic architecture of human pain perception. Trends Genet 2007; 23: 605-13.

[40] Tegeder I, Costigan M, Griffin RS, et al. GTP cyclohydrolase and tetrahydrobiopterin regulate pain sensitivity and persistence. Nat Med 2006; 12: 1269-77.

[41] Taenzer P, Melzack R, Jeans ME. Influence of psychological factors on postoperative pain, mood and analgesic requirements. Pain 1986; 24: 331-42. 
[42] Axelrod DA, Proctor MC, Geisser ME, Roth RS, Greenfield LJ. Outcomes after surgery for thoracic outlet syndrome. J Vasc Surg 2001; 33: 1220-5.

[43] Brandsborg B, Nikolajsen L, Hansen CT, Kehlet H, Jensen TS. Risk factors for chronic pain after hysterectomy: a nationwide questionnaire and database study. Anesthesiology 2007; 106: 1003-12.

[44] Aasvang E, Kehlet $\mathrm{H}$. Chronic postoperative pain: the case of inguinal herniorrhaphy. Br J Anaesth 2005; 95: 69-76.

[45] Wildgaard K, Ravn J, Kehlet H. Chronic post-thoracotomy pain: a critical review of pathogenic mechanisms and strategies for prevention. Eur J Cardiothorac Surg 2009; 36: 170-80.

[46] Nielsen PR, Norgaard L, Rasmussen LS, Kehlet H. Prediction of post-operative pain by an electrical pain stimulus. Acta Anaesthesiol Scand 2007; 51: 582-6.

[47] Werner $M U$, Duun $P$, Kehlet $H$. Prediction of postoperative pain by preoperative nociceptive responses to heat stimulation. Anesthesiology 2004; 100: 115-9; discussion 5A.

[48] Granot M, Lowenstein L, Yarnitsky D, Tamir A, Zimmer EZ. Postcesarean section pain prediction by preoperative experimental pain assessment. Anesthesiology 2003; 98 : 1422-6.

[49] Lundblad H, Kreicbergs A, Jansson KA. Prediction of persistent pain after total knee replacement for osteoarthritis. J Bone Joint Surg Br 2008; 90: 166-71.

[50] Maguire MF, Latter JA, Mahajan R, Beggs FD, Duffy JP. A study exploring the role of intercostal nerve damage in chronic pain after thoracic surgery. Eur J Cardiothorac Surg 2006; 29: 873-9.

[51] Gwak MS, Yang M, Hahm TS, Cho HS, Cho CH, Song JG. Effect of cryoanalgesia combined with intravenous continuous analgesia in thoracotomy patients. J Korean Med Sci 2004; 19: 74-8.

[52] Koehler RP, Keenan RJ. Management of postthoracotomy pain: acute and chronic. Thorac Surg Clin 2006; 16: 287-97.

[53] Kaplan J SP. Thoracic Anesthesia; 2003.

[54] Benedetti F, Vighetti S, Ricco C, et al. Neurophysiologic assessment of nerve impairment in posterolateral and muscle-sparing thoracotomy. J Thorac Cardiovasc Surg 1998; 115: 841-7.

[55] d'Amours RH, Riegler FX, Little AG. Pathogenesis and management of persistent postthoracotomy pain. Chest Surg Clin N Am 1998; 8: 703-22.

[56] Perkins FM, Kehlet $H$. Chronic pain as an outcome of surgery. A review of predictive factors. Anesthesiology 2000; 93: 1123-33.

[57] Keller SM, Carp NZ, Levy MN, Rosen SM. Chronic post thoracotomy pain. J Cardiovasc Surg (Torino) 1994; 35: 161-4.

[58] Ali M, Winter DC, Hanly AM, O'Hagan C, Keaveny J, Broe P. Prospective, randomized, controlled trial of thoracic epidural or patient-controlled opiate analgesia on perioperative quality of life. Br J Anaesth; 104: 292-7.

[59] Joshi GP, Bonnet F, Shah $R$, et al. A systematic review of randomized trials evaluating regional techniques for postthoracotomy analgesia. Anesth Analg 2008; 107: 102640.

[60] Scarci M, Joshi A, Attia R. In patients undergoing thoracic surgery is paravertebral block as effective as epidural analgesia for pain management? Interact Cardiovasc Thorac Surg; 10: 92-6. 
[61] Wenk M, Schug SA. Perioperative pain management after thoracotomy. Curr Opin Anaesthesiol.

[62] Nesher N, Ekstein MP, Paz Y, Marouani N, Chazan S, Weinbroum AA. Morphine with adjuvant ketamine vs higher dose of morphine alone for immediate postthoracotomy analgesia. Chest 2009; 136: 245-52.

[63] Duale C, Sibaud F, Guastella V, et al. Perioperative ketamine does not prevent chronic pain after thoracotomy. Eur J Pain 2009; 13: 497-505.

[64] Senard M, Deflandre EP, Ledoux D, et al. Effect of celecoxib combined with thoracic epidural analgesia on pain after thoracotomy. Br J Anaesth; 105: 196-200.

[65] Argiriadou H, Papagiannopoulou P, Foroulis CN, et al. Intraoperative Infusion of S(+)Ketamine Enhances Post-thoracotomy Pain Control Compared With Perioperative Parecoxib When Used in Conjunction With Thoracic Paravertebral Ropivacaine Infusion. J Cardiothorac Vasc Anesth.

[66] Ihmsen H, Geisslinger G, Schuttler J. Stereoselective pharmacokinetics of ketamine: R(-)ketamine inhibits the elimination of S(+)-ketamine. Clin Pharmacol Ther 2001; 70: 431-8.

[67] Himmelseher S, Durieux ME. Ketamine for perioperative pain management. Anesthesiology 2005; 102: 211-20.

[68] Doenicke A, Kugler J, Mayer M, Angster R, Hoffmann P. [Ketamine racemate or S-(+)ketamine and midazolam. The effect on vigilance, efficacy and subjective findings]. Anaesthesist 1992; 41: 610-8.

[69] Suzuki M, Haraguti S, Sugimoto K, Kikutani T, Shimada Y, Sakamoto A. Low-dose intravenous ketamine potentiates epidural analgesia after thoracotomy. Anesthesiology 2006; 105: 111-9.

[70] De Kock M, Lavand'homme P, Waterloos $H$. 'Balanced analgesia' in the perioperative 70period: is there a place for ketamine? Pain 2001; 92: 373-80.

[71] Annetta MG, Iemma D, Garisto C, Tafani C, Proietti R. Ketamine: new indications for an old drug. Curr Drug Targets 2005; 6: 789-94.

[72] Senturk M, Ozcan PE, Talu GK, et al. The effects of three different analgesia techniques on long-term postthoracotomy pain. Anesth Analg 2002; 94: 11-5, table of contents.

[73] Mao J, Price DD, Mayer DJ. Mechanisms of hyperalgesia and morphine tolerance: a current view of their possible interactions. Pain 1995; 62: 259-74.

[74] Tucker AP, Kim YI, Nadeson R, Goodchild CS. Investigation of the potentiation of the analgesic effects of fentanyl by ketamine in humans: a double-blinded, randomised, placebo controlled, crossover study of experimental pain[ISRCTN83088383]. BMC Anesthesiol 2005; 5: 2.

[75] Ozyalcin NS, Yucel A, Camlica H, Dereli N, Andersen OK, Arendt-Nielsen L. Effect of preemptive ketamine on sensory changes and postoperative pain after thoracotomy: comparison of epidural and intramuscular routes. Br J Anaesth 2004; 93: 356-61.

[76] Obata K, Yamanaka H, Kobayashi K, et al. The effect of site and type of nerve injury on the expression of brain-derived neurotrophic factor in the dorsal root ganglion and on neuropathic pain behavior. Neuroscience 2006; 137: 961-70.

[77] Snijdelaar DG, Koren G, Katz J. Effects of perioperative oral amantadine on postoperative pain and morphine consumption in patients after radical prostatectomy: results of a preliminary study. Anesthesiology 2004; 100: 134-41. 


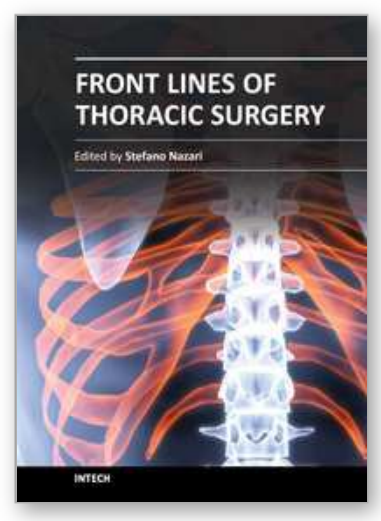

\author{
Front Lines of Thoracic Surgery \\ Edited by Dr. Stefano Nazari
}

ISBN 978-953-307-915-8

Hard cover, 412 pages

Publisher InTech

Published online 03, February, 2012

Published in print edition February, 2012

Front Lines of Thoracic Surgery collects up-to-date contributions on some of the most debated topics in today's clinical practice of cardiac, aortic, and general thoracic surgery,and anesthesia as viewed by authors personally involved in their evolution. The strong and genuine enthusiasm of the authors was clearly perceptible in all their contributions and I'm sure that will further stimulate the reader to understand their messages. Moreover, the strict adhesion of the authors' original observations and findings to the evidence base proves that facts are the best guarantee of scientific value. This is not a standard textbook where the whole discipline is organically presented, but authors' contributions are simply listed in their pertaining subclasses of Thoracic Surgery. I'm sure that this original and very promising editorial format which has and free availability at its core further increases this book's value and it will be of interest to healthcare professionals and scientists dedicated to this field.

\title{
How to reference
}

In order to correctly reference this scholarly work, feel free to copy and paste the following:

F. Della Corte, C. Mendola, A. Messina and G. Cammarota (2012). Post Thoracotomy Pain Syndrome, Front Lines of Thoracic Surgery, Dr. Stefano Nazari (Ed.), ISBN: 978-953-307-915-8, InTech, Available from: http://www.intechopen.com/books/front-lines-of-thoracic-surgery/post-thoracotomy-pain-syndrome

\section{INTECH}

open science | open minds

\author{
InTech Europe \\ University Campus STeP Ri \\ Slavka Krautzeka 83/A \\ 51000 Rijeka, Croatia \\ Phone: +385 (51) 770447 \\ Fax: +385 (51) 686166 \\ www.intechopen.com
}

\author{
InTech China \\ Unit 405, Office Block, Hotel Equatorial Shanghai \\ No.65, Yan An Road (West), Shanghai, 200040, China \\ 中国上海市延安西路65号上海国际贵都大饭店办公楼 405 单元 \\ Phone: +86-21-62489820 \\ Fax: +86-21-62489821
}


(C) 2012 The Author(s). Licensee IntechOpen. This is an open access article distributed under the terms of the Creative Commons Attribution 3.0 License, which permits unrestricted use, distribution, and reproduction in any medium, provided the original work is properly cited. 